\title{
PELAKSANAAN PERJANJIAN JASA BORDIR SECARA LISAN ANTARA PELAKU USAHA DENGAN PELANGGAN DALAM HAL TERJADI WANPRESTASI
}

\author{
Widjiarti, Sukresno dan Suciningtyas
}

Email : widjiarti62@gmail.com, sukresno@umk.ac.id, suciningtyas@umk.ac.id Fakultas Hukum Universitas Muria Kudus

\begin{abstract}
ABSTRAK
Tentang pelaksanaan perjanjian secara lisan antara pelaku usaha bordir dengan pelanggan dalam hal terjadi wanprestasi, tindakan yang diambil oleh pelaku usaha bordir dalam menyelesaikan pelanggan yang wanprestasi dan kendala-kendala yang muncul dalam pelaksanaan perjanjian secara lisan antara pelaku usaha bordir dengan pelanggan. Metode pendekatan yang digunakan dalam penelitian ini adalah yuridis sosiologis. Spesifikasi penelitian menggunakan deskriptif analistis, metode penentuan sampel dengan non random sampling. Teknik pengumpulan data, dilakukan melalui studi lapangan dan studi kepustakaan. Teknik pengolahan data dengan cara memeriksa dan meneliti data, dengan tujuan untuk menjamin akurasi data dan data tersebut dapat dipertanggung jawabkan. Dari hasil penelitian dan pembahasan dapat diketahui bahwa ketiga pengusaha bordir yaitu UD. Bimatex Embroidery, UD. Dua Putri dan CV. Barokhah dalam melaksanakan pengerjaan bordir dengan pelanggan menggunakan perjanjian secara lisan. Dari ketiga pengusaha bordir sebagaimana tersebut mempunyai pelanggan yang wanprestasi. Apabila ada pelanggan yang wanprestasi, maka, penyelesaiannya dengan cara pelanggan yang menunggak membayar dengan cara mengangsur, atau dapat juga dengan memberikan harta benda seperti sepeda motor dan mobil untuk membayar kekurangan pembayaran bordir. Adapun kendala yang muncul dalam perjanjian secara lisan antara pengusaha bordir dengan pelanggan adalah pelanggan mengingkari jika dirinya mempunyai hutang kepada pengusaha bordir, pelanggan pindah rumah, pelanggan susah dihubungi dan kurang bukti jika akan melakukan gugatan.
\end{abstract}

Kata Kunci : Perjanjian Lisan, Pelanggan, Wanprestasi 


\section{PENDAHULUAN}

Kudus merupakan kota dengan wilayah terkecil di Jawa Tengah, namun kegiatan perekonomian di kota Kudus seakan tak pernah berhenti, mulai dari Industri rokok, konveksi dan usaha bordir computer. Usahana konveksi yang berkembang pesat akhir-akhir ini menuntut pengusaha untuk mengembangkan produksi, salah satunya dengan membuat motif pada baju muslim pria dan wanita, kerudung (jilbab) dan lencana/symbol-simbol dan papan nama. Hal ini membuat pengusaha konveksi harus bekerja sama dengan pengusaha bordir.

Dalam praktik, pengusaha bordir di kota Kudus dalam melakukan kegiatan transaksi order bordir antara pengusaha bordir dengan pelanggan menggunakan asas kepercayaan atau dengan menggunakan perjanjian secara lisan. ${ }^{73}$ Cara yang biasa digunakan yaitu pihak pelanggan bordir mengirim barang kepada pengusaha jasa bordir, selanjutnya setelah terjadi kesepakatan pelanggan memberikan uang muka (down payment), setelah itu baru dimulai pekerjaan membordir. Pengusaha bordir pada umumnya sudah mempunyai pelanggan tetap, pelangganpelanggan ini tidak hanya sekali dalam memberikan order bordir kepada pengusaha bordir.

Dalam praktiknya, pelaksanaan perjanjian jasa bordir dengan pelanggan secara lisan memiliki risiko, yaitu terjadinya wanprestasi (tidak terbayarnya sisa biaya bordir). Menurut Wirjono Prodjodikoro wanprestasi adalah ketiadaan suatu prestasi didalam hukum perjanjian yang harus

\footnotetext{
73 Sutikman, Wawancara Pra Survey, Pengusaha bordir, pemilik UD. Bimatex Embroidery pada tanggal 19 Juni 2018
}

dilaksanakan sebagai isi dari suatu perjanjian. $^{74}$ Wanprestasi menurut Salim HS adalah tidak memenuhi atau lalai atau ingkar janji dalam melaksanakan kewajiban (prestasi) sebagaimana yang ditentukan dalam perjanjian yang dibuat antara kreditor dengan debitor. ${ }^{75}$ Dalam hal ini kaitannya antara pelanggan yang tidak dapat memberikan prestasi atas jasa bordir kepada pelanggan bordir yang telah disepakati secara lisan.

Wanprestasi para pelanggan bordir pada umumnya lalai tidak melaksanakan prestasinya atas usaha jasa bordir. Kesepakatannya adalah apabila proses pekerjaan bordir sudah selesai, maka pelanggan membayar kekurangan biaya bordir, tetapi dalam praktik masih ada pelanggan yang menunggak sisa pembayaran. Salah satu pengusaha bordir di kota Kudus Sutikman pemilik UD Bimatex Embroidery memberikan penjelasan, bahwa dengan adanya wanprestasi, jelas sangat merugikan pelaku usaha bordir, karena bisnis bordir bersinggungan dengan biaya produksi dan gaji karyawan. $^{76}$

Jasa bordir dalam melaksanakan pekerjaan border pelanggannya dengan perjanjian lisan, pada dasarnya baik perjanjian lisan maupun perjanjian tertulis mempunyai risiko yang sama, yaitu wanprestasi. Namun, perjanjian secara lisan mempunyai risiko lebih besar, karena perjanjian lisan berdasarkan atas kepercayaan,

\footnotetext{
74 Wirjono Prodjodikoro, Asas-asas Hukum Perjanjian, Sumur, Bandung, 2000, hlm.17

${ }^{75}$ Salim HS, Hukum Kontrak: Teori dan Teknik Penyusunan Kontrak, Sinar Grafika, Jakarta, 2003, hlm. 98.

76 Sutikman selaku Pelaku Usaha Dagang Bimatex Embroidery, Wawancara Pra Survey, pada tanggal 19 Juni 2018
} 
sebagaimana yang dialami oleh Sutikman pemilik usaha bordir UD Bimatex Embroidery dengan pelanggan, selain risiko wanprestasi, pengusaha bordir terkendala dengan modal usaha, karena dengan munculnya wanprestasi dari para pelanggan, maka akan mengurangi modal pengusaha bordir guna untuk menutup biaya produksi. Apabila konsumen tidak segera melunasi atau membayar sisa pelunasan pembayaran, maka tentu merugikan pemilik usaha UD Bimatex Embroidery. $^{77}$

Berdasarkan latar belakang di atas, maka tertarik penelitian untuk melakukan penelitian dengan judul "Pelaksanaan Perjanjian Jasa Bordir Secara Lisan Antara Pelaku Usaha Dengan Pelanggan Dalam Hal Terjadi Wanprestasi". Berdasarkan latar belakang sebagaimana tersebut di atas, maka permasalahan yang akan diteliti dalam penelitian ini adalah sebagai berikut :

1. Bagaimanakah Pelaksanaan Perjanjian secara lisan antara pelaku usaha bordir dengan pelanggan dalam hal terjadi wanprestasi ?

2. Apa tindakan yang diambil oleh pelaku usaha bordir dalam menyelesaikan pelanggan yang wanprestasi ?

3. Kendala-kendala apa yang muncul dalam pelaksanaan perjanjian secara lisan antara pelaku usaha bordir dengan pelanggan?

\section{METODE PENELITIAN}

Pendekatan masalah dalam penelitian ini yaitu yuridis empiris. Penelitian yuridis empiris menurut Dyah Ochtorina Susanti dan A'an

\footnotetext{
77 Sutikman selaku Pelaku Usaha Dagang Bimatex Embroidery, Wawancara Pra Survey, pada tanggal 19 Juni 2018
}

Efendi yaitu penelitian hukum sosiologis/empiris meliputi penelitian terhadap identifikasi hukum (hukum tidak tertulis) dan penelitian terhadap efektifitas hukum. ${ }^{78}$ Penelitian empiris ini mencakup identifikasi hukum dan efektifitas penerapan hukum dalam masyarakat dan juga mempelajari aturan-aturan hukum yang berkaitan dengan objek yang diteliti, yaitu penerapan hukum perjanjian yang terjadi di masyarakat sebagaimana diatur dalam KUHPerdata.

Dalam upaya untuk memperoleh data yang akurat, diperlukan langkahlangkah serta teknik yang tepat. Sesuai dengan metode pendekatan yang digunakan, yaitu yuridis empiris, maka data utamanya adalah data primer dan data sekunder sebagai data pendukung. Data primer diperoleh dengan melakukan studi lapangan dengan cara wawancara, sedangkan data sekunder diperoleh dengan melakukan studi kepustakaan.

\section{HASIL PENELITIAN DAN PEMBAHASAN}

\section{A. Pelaksanaan Perjanjian Secara Lisan Antara Pelaku Usaha Bordir dengan Pelanggan dalam Hal Terjadi Wanprestasi}

Pelaku usaha bordir seperti UD. Bimatex Embroidery milik Sutikman, UD. Dua Putri milik H. Abdillah Noor dan CV. Barokhah milik H. Mustakhim, ketiganya adalah pengusaha bordir sebagaimana tersebut di atas, masingmasing mempunyai pelanggan yang wanprestasi.

\footnotetext{
${ }^{78}$ Dyah Ochtorina Susanti dan A'an Efendi, Penelitian Hukum (Legal Research), Sinar Grafika, Jakarta, 2014, hlm. 18
} 
Dalam melakukan pekerjaan, antara pengusaha bordir dengan pelanggan menggunakan perjanjian lisan. Perjanjian yang disepakatai yaitu pelanggan memberikan uang muka tanda jadi dan kekurangan pembayaran akan dilunasi jika pekerjaan bordir sudah selesai.

Perjanjian merupakan janji yang disepakati oleh para pihak yang melakukan perjanjian untuk melakukan atau tidak melakukan sesuatu dengan cuma-cuma atau dengan memberatkan, maka, dalam perjanjian harus disebutkan apakah suatu perjanjian itu dilakukan dengan cuma-cuma atau dengan memberatkan. Hal ini sebagaimana diatur Pasal 1319 KUHPerdata $:{ }^{79}$

"Suatu persetujuan diadakan dengan cuma-cuma atau dengan memberatkan. Suatu persetujuan cuma-cuma adalah suatu persetujuan, bahwa pihak yang satu akan memberikan suatu keuntungan kepada pihak yang lain tanpa menerima imbalan. Suatu persetujuan memberatkan adalah suatu persetujuan yang mewajibkan tiap pihak untuk memberikan sesuatu, melakukan sesuatu atau tidak melakukan sesuatu." 80

UD. Bimatex Embroidery, milik Sutikman sudah terbiasa melakukan perjanjian lisan dengan pelanggannya. UD Bimatex Embroidery sebagai pelaku usaha juga sudah terbiasa menghadapi pelanggannya yang wanprestasi atau cidera janji. Pelanggan UD. Bimatex Embroidery yang wanprestasi dikarenakan usahanya baru

\footnotetext{
${ }^{79}$ Ahmadi Miru \& Sakka Pati, Hukum Perikatan (Penjelasan Makna Pasal 1233 - 1456 KUH PERDATA), Rajawali Pers, 2011, Jakarta, hlm. 60

${ }^{80}$ Subekti, Hukum Perjanjian, Intermasa, 2010, Jakarta, hlm.11
}

mengalami kemunduran sehingga tidak dapat melunasi kekurangan pembayaran biaya bordir.

Dalam penelitian ini penulis melakukan penelitian di 3 (tiga) lokasi pemilik usaha bordir yaitu :

\section{UD. Bimatex Embroidery}

Menurut Sutikman pemilik UD. Bimatex Embroidery, terjadinya wanprestasi atas pembayaran biaya borrdir oleh pelanggan, karena barang dagangann pelanggan yang belum laku dan belum dibayar oleh distributor dan pedagang di pasar. Menghadapi pelanggan yang wanprestasi, pihak manajemen UD. Bimatex Embroidery, tetap memberikan toleransi kepada pelanggan. Pemberian toleransi kepada pelanggan yang wanprestasi, tujuannya adalah memberikan kepercayaan kepada pelanggan untuk melunasi semua hutangnya pada UD. Bimatex Embroidery. ${ }^{81}$

Pelanggan UD. Bimatex Embroidery yang pernah wanprestasi yaitu CV. ANT milik MNR dan UD KML milik UHL, kedua palanggan UD Bimatex Embroidery bergerak di bidang konveksi, untuk CV. ANT bergerak di bidang pembuatan jilbab sedangkan UD. KML bergerak di bidang pembuatan kaos olah raga dan baju muslim khusus pria (baju koko). Sistem kerja UD. Bimatex Embroidery yaitu dengan menggunakan perjanjian secara lisan, atau saling percaya. ${ }^{82}$

Pemilik UD. Bimatex Embroidery, memberikan kemudahan kepada pelanggan yang menunggak pembayaran biaya bordir untuk

81 Sutikman, Wawancara pribadi, Pengusaha bordir, pemilik UD Bimatex Embroidery pada tanggal 19 Juni 2018

82 Sutikman, Wawancara pribadi, Pengusaha bordir, pemilik UD Bimatex Embroidery pada tanggal 19 Juni 2018 
membayar tunggakan secara mengangsur. ${ }^{83}$ Hal ini dibenarkan oleh pemilik CV ANT yaitu MNR yang memberikan keterangan kepada penulis bahwa selama ini CV. ANT memang mempunyai tunggakan biaya bordir pakaian yang belum terbayar, namun pemilik UD. Bimatex Embroidery tetap memberikan kepercayaan kepada CV. ANT untuk melunasi tunggakan hutangnya secara mengangsur. Menurut pemilik usaha bordir MNR, pihaknya memberikan batas waktu paling lama 12 kali angsuran. ${ }^{84}$ Hal yang sama juga dikatakan oleh pemilik UD. KML yaitu UHL bahwa pada dasarnya pemilik usaha bordir, tetap memberikan kepercayaan kepada pelanggannya khususnya UD. KML. ${ }^{85}$

Pemilik bordir tetap memberikan kepercayaan. karena para pelanggan yang wanprestasi masih mempunyai itikat baik bersedia membayar meskipun mengangsur, dan selama angsuran belum lunas, pelanggan memberikan jaminan sepeda motor atau mobil, jika angsuran sudah lunas, maka sepeda motor atau mobil dapat diambil oleh pelanggan. ${ }^{86}$

\section{UD. Dua Putri}

Pengusaha bordir lainnya yang pernah mengalami pelanggannya wanprestasi yaitu UD. Dua Putri milik H. Abdillah Noor yang ada di desa Jati Wetan Kecamatan Jati. Pelanggan yang pernah wanprestasi di UD Dua Putri

83 H. Abdillah Noor, Wawancara pribadi, Pengusaha Bordir UD Dua Putri, tanggal 22 Juni 2018.

${ }^{84}$ MNR, wawancara pribadi, Pemilik CV ANT, tanggal 26 Juni 2018.

${ }^{85}$ UHL, wawancara pribadi, Pemilik UD KML, tanggal 25 Juni 2018.

86 Sutikman, wawancara pribadi, Pengusaha bordir, pemilik UD Bimatex Embroidery pada tanggal 19 Juni 2018. usaha bordir milik H. Abdillah Noor, yaitu UD. CMR milik H. SDR dan UD. BRK milik Mukidin (nama disamarkan) yang bergerak dibidang konveksi membuat baju muslim pria dan wanita. $^{87}$ Mukidin memberikan keterangan bahwa uang muka untuk pekerjaan membordir UD. Dua Putri meminta $80 \%$ dari jumlah dana yang harus dibayar. Mukidin juga membenarkan bahwa dirinya pernah menunggak sisa pembayaran, namun pemilik UD Dua Putri memberikan kebijaksanaan kepada Mukidin untuk membayar dengan cara mengangsur, tetapi yang bersangkutan (Mukidin) lebih memilih membayar hutangnya dengan kendaraan bermotor sebanyak 2 (dua) unit, dengan demikian Mukidin tidak mempunyai hutang pada UD. Dua Putri. ${ }^{88}$

UD. CMR telah cukup lama menjadi pelanggan bordir di UD. Dua Putri, namun, dengan berjalannya waktu usaha konveksi UD. CMR mengalami kemunduran dalam usahannya, maka akibatnya sampai tidak mampu melunasi hutangnya pada UD. Dua Putri. Pihak manajeman UD Dua Putri tetap memberikan toleransi kepada UD CMR milik H. SDR untuk melunasi hutangnya dengan cara mengangsur yang jumlahnya ditentukan oleh manajemen UD Dua Putri, yang ditentukan hanya angsuran minimalnya yang diambil dari jumlah hutang yang tersisa, sebagi contoh apabila pelanggan berhutang sebesar 20 juta maka angsuran minimalnya sebesar $10 \%$ dari 20 juta. Lama angsuran menurut

87 H. Abdillah Noor, wawancara pribadi, Pengusaha Bordir UD Dua Putri, tanggal 22 Juni 2018

88 Mukidin, wawancara pribadi, Pelanggan Bordir UD Dua Putri Desa Jati Kecamatan Jati, tanggal 28 Juni 2018. 
pemilik usaha bordir UD. Dua Putri maksimal 10 kali angsuran. Apab ila 10 kali angsuran belum selesai, maka pemilik UD. Dua Putri meminta jaminan seperti sepeda motor atau mobil. $^{89}$

\section{CV. Barokah}

CV. Barokah bergerak di bidang bordir, semua jenis bordir diterima oleh CV. Barokah. Pemilik CV. Barokah adalah H. Mustakhim, alamat CV. Barokah ada di Desa Prambatan Lor Kecamatan Kaliwungu Kabupaten Kudus.

Dalam menghadapai pelanggan yang nakal, pemilik usaha bordir CV. Barokhah, dengan tegas membatasi hutang pelanggan. Apabila ada pelanggannya yang sudah tiga kali tidak dapat melunasi hutangnya, maka untuk order selanjutnya harus dibayar kontan, karena hal ini menyangkut kelangsungan usaha bordirnya. Wanprestasi pelanggan dapat mengganggu masalah keuangan, sebab menyangkut masalah gaji karyawan dan bahan-bahan bordir seperti benang serta biaya perawatan mesin bordir computer, yang sangat jelas membutuhkan biaya yang besar. ${ }^{90}$

Salah satu pelanggan CV Barokhah, PLT memberikan keterangan bahwa H. Mustakhim sangat tegas, artinya apabila ada pelanggannya yang menunggak lebih dari 2 (dua) nota, maka H. Mustakhim akan selalu melakukan penagihan secara berkala. Jika pelanggan tetap tidak mampu membayar, maka H. Mustakhim tidak bersedia menerima pekerjaan

\footnotetext{
${ }^{89}$ H. SDR, wawancara pribadi, Pelanggan Bordir UD Dua Putri, tanggal 24 Juni 2018.

${ }^{90} \mathrm{H}$. Mustakhim, wawancara pribadi, Pemilik CV Barokhah, tanggal 29 Juni 2018.
}

membordir lagi dari pelanggannya tersebut. Meskipun bersikap tegas $\mathrm{H}$. Mustakhim tetap memberikan toleransi dalam memimpin perusahaannya. ${ }^{91}$ PLT juga pernah menunggak sampai tiga kali pembayaran atau tiga nota, maka konsekwensinya untuk order pengerjaan selanjutnya harus dibayar kontan. Hal tersebut tidak membuat sakit hati pelanggan, karena memang itu sudah menjadi aturan dan keputusan bersama yang telah disepakati antara pemilik usaha bordir dengan pelanggan di dalam perjanjian lisan. $^{92}$

Hal yang sama juga dikatakan oleh KL, yang sudah menjadi pelanggan CV Barokhah sejak tahun 2007. KL sebagai pelanggan bordir CV Barokhah juga pernah wanprestasi. KL membuat kesepakatan dengan pemilik $\mathrm{CV}$ Barokhah akan melunasi hutangnya selama 2 bulan dan sebagai jaminan hutang KL memberikan 2 (dua) unit sepeda motor. Sesuai dengan janji KL, sebulan kemudian hutangnya dilunasi. ${ }^{93}$

\section{B. Tindakan yang Dilakukan Oleh Pelaku Usaha Bordir dalam Menyelesaikan Pelanggan yang Wanprestasi}

Penyelesaian terhadap pelanggan yang wanprestasi, pengusaha bordir bersikap tegas, untuk UD. Bimatex Embroidery milik Sutikman memberikan kesempatan kepada pelanggannya untuk mengangsur sisa pembayaran yang tertunggak, UD. Dua Putri milik H. Abdillah Noor dalam menghadapi pelanggan yang

\footnotetext{
91 PLT, wawancara pribadi, Pelanggan Bordir CV Barokhah, 5 Juli 2018

92 PLT, wawancara pribadi, Pelanggan Bordir CV Barokhah, 5 Juli 2018

$93 \mathrm{KL}$, wawancara pribadi, Pelanggan Bordir CV Barokhak, 5 Juli 2018
} 
wanprestasi, pemilik UD Dua Putri, tetap memberikan pelayanan jasa bordir, hal ini dikarenakan, apabila tidak diterima order bordir dari pelanggan sebagaimana tersebut, maka pelanggan tidak dapat mengangsur tunggakan biaya bordir yang belum terbayar dan CV. Barokhah milik $\mathrm{H}$. Mustakhim dalam menghadapai pelanggan yang wanprestasi tetap pelayanan kepada pelanggan tersebut, karena memang usaha pelanggan baru mengalami kemunduran, tetapi hanya dibatasi sampai 3 (tiga) kali order bordir harus lunas.

Namun, dari sekian banyaknya pelanggan bordir ada beberapa pelanggan yang menunggak atau wanprestasi. Dari ketiga perusahaan bordir yang diteliti oleh penulis, penyelesaian terhadap pelanggan yang wanprestasi yaitu sebagai berikut :

\section{UD. Bimatex Embroidery}

Sutikman adalah pemilik UD Bimatex Embroidery, memberikan keterangan bahwa sampai saat penulis melakukan wawancara dengan Sutikman pelanggannya yang wanprestasi atau yang menunggak ada 4 (empat) orang, tetapi penulis hanya mengambil sampel 2 orang pelanggan UD. Bimatex Embroidery yang wanprestasi yaitu CV. ANT milik MNR dan UD. KML milik UHL. Penyelesaian wanprestasi di UD. Bimatex Embroidery, terhadap pelanggan yang menunggak yaitu dengan cara memberikan kesempatan kepada pelangganya untuk mengangsur sisa pembayaran yang tertunggak.

Namun, apabila pelanggan tidak dapat mengangsur setiap bulan, maka pemilik UD. Bimatex Embroidery memberikan pilihan kepada pelanggan, yaitu menyerahkan barang yang dapat dijadikan jaminan, sehingga pelanggan akan sungguh-sungguh untuk melunasi hutangnya pada pemilik usaha bordir. UD. Bimatex Embroidery pernah menerima jaminan mobil dari pelanggan yang wanprestasi, dari salah satu pelanggan yaitu UD KML milik UHL, tetapi mobil yang dijadikan jaminan akhirnya diambil pemiliknya lagi, karena hutangnya sudah lunas. Namun, apabila pelanggan memberikan jaminan sepeda motor, pemilik bordir tetap menerima, meskipun nilai jual sepeda motor tidak sebanding dengan hutangnya, tetapi yang dinilai oleh pemilik usaha bordir bukan nilai sepeda motornya, tetapi niat dan itikat baik dari pelanggan tersebut. ${ }^{94}$

Hal sebagaimana tersebut di atas, dibenarkan oleh pemilik UD. KML yaitu UHL, yang memberikan keterangan kepada penulis bahwa usahannya pernah mengalami kemunduruan dan tidak mampu membayar tunggakan tagihan bordir pada UD. Bimatex Embroidery. Namun, karena UHL merasa memiliki hubungan yang sangat baik dengan pemilik usaha bordir UD. Bimatex Embroidery, maka UHL memberikan kendaraan sepeda motor untuk melunasi hutangnya dan disetujui oleh pemilik UD Bimatex Embroidery. ${ }^{95}$ Meskipun dengan memberikan sepeda motor belum mampu menutup jumlah hutangnya, namun, hal tersebut merupakan bentuk tanggung jawab yang baik demi menjaga hubungan kerja dengan pengusaha. Sisa kekurangan pembayaran diangsur tiap bulan, dengan

\footnotetext{
94 Sutikman, Wawancara pribadi, Pengusaha bordir, pemilik UD. Bimatex Embroidery pada tanggal 9 Juli 2018.

${ }^{95}$ UHL, Wawancara pribadi, Pemilik UD. KML, tanggal 5 Juli 2018.
} 
maksimal 10 kali pembayaran harus lunas. ${ }^{96}$

\section{UD. Dua Putri}

UD. Dua Putri adalah perusahaan bordir milik H. Abdillah Noor, yang beralamat di desa Jati Kecamatan Jati Kabupaten Kudus. Pelanggan bordir di UD. Dua Putri rata-rata adalah pengusaha konveksi baju muslim pria dan wanita, ada juga pelanggan konveksi yang membuat kerudung. $\mathrm{H}$. Abdillah Noor dalam wawancara dengan penulis memberikan keterangan bahwa selama ini masih ada pelanggannya yang menunggak pembayaran. $^{97}$

Sampai saat penulis melakukan wawancara dengan pemilik UD Dua Putri H. Abdillah Noor, ada beberapa pelanggan yang wanprestasi, kurang lebih ada 5 (lima) orang pelanggan yang wanprestasi. Dalam menghadapi pelanggan yang wanprestasi, pemilik UD. Dua Putri, tetap memberikan pelayanan jasa bordir, hal ini dikarenakan, apabila tidak diterima order bordir dari pelanggan sebagaimana tersebut, maka pelanggan tidak dapat mengangsur tunggakan biaya bordir yang belum terbayar. Dalam menyelesaikan hutang piutang, H. Abdillah Noor, memberikan kebijaksanaan kepada pelanggan untuk membayar dengan cara mengangsur setiap bulan atau setiap 2 minggu sekali. Alasan H. Abdillah Noor memberikan kebijaksanaan tersebut adalah karena selama ini pelanggannya adalah pelanggan yang baik dan jujur, dan

\footnotetext{
${ }^{96}$ Sutikman, Wawancara pribadi, Pengusaha bordir, pemilik UD. Bimatex Embroidery pada tanggal 9 Juli 2018.

${ }^{97} \mathrm{H}$. Abdillah Noor, Wawancara pribadi, Pengusaha Bordir UD. Dua Putri, tanggal 24 Juni 2018.
}

selama jadi pelanggannya tidak pernah menunggak pembayaran biaya bordir. ${ }^{98}$

Terjadinya wanprestasi karena usaha pelanggannya memang baru mengalami kemunduran dalam usaha, dengan alasan sebagaimana tersebut di atas, H. Abdillah Noor memberikan kebijaksanaan kepada pelanggannya dengan harapan masih dapat melakukan kerja sama dan saling bantu membantu. Bagi H. Abdillah Noor yang terpenting adalah niat dan usaha pelanggan untuk melunasi sisa pembayaran. ${ }^{99}$

\section{CV. Barokhah}

H. Mustakhim adalah pemilik CV Barokhah usaha bordirnya dirintis sejak tahun 1992 ssampai sekarang 2018. Pelanggan CV Barokhah dari berbagai daerah, tidak hanya dari kabupaten Kudus saja, tetapi pelanggan CV Barokhah ada yang dari luar Kabupaten Kudus, seperti dari Kabupaten Jepara, Kabupaten Pati dan dari Kabupaten Grobogan. Berbagai macam tipe pelanggan yang dihadapai oleh $\mathrm{H}$. Mustakhim, ada yang memang pelanggan baik ada juga pelanggan yang memang tidak mempunyai niat baik. $^{100}$

Menurut H. Mustakhim, pelanggan yang baik adalah pelanggan yang memang ingin menjadikan UD Barokhah sebagai mitra kerja, dan selalu menepati janji, sedangkan pelanggan yang tidak baik yaitu pelanggan yang hanya sekali memberikan order kepada UD Barokhah dan setelah itu tidak

98 H. Abdillah Noor, Wawancara pribadi, Pengusaha Bordir UD Dua Putri, tanggal 24 Juni 2018.

99 H. Abdillah Noor, Wawancara pribadi, Pengusaha Bordir UD. Dua Putri, tanggal 24 Juni 2018.

100 H. Mustakhim, Wawancara pribadi, Pemilik CV. Barokhah, tanggal 5 Juli 2018. 
membayar sisa biaya bordir. Dalam mengahadapi pelanggan yang wanprestasi, baik itu pelanggan yang baik dan pelanggan yang tidak baik, $\mathrm{H}$. Mustakhim memperlakukannya secara berbeda.

Dalam menghadapi pelanggan yang baik yang wanprestasi, $\mathrm{H}$. Mustakhim memberikan keterangan bahwa pelanggannya tersebut baru mengalami kemunduran dalam usahanya. Pada saat usahanya berjalan dengan baik, pelanggannya tersebut belum pernah menunggak, sehingga setiap pelanggan yang menunggak ada alasannya. Pelanggan yang wanprestasi sebagaimana tersebut diatas, $\mathrm{H}$. Mustakhim memberikan toleransi yaitu tetap menerima order bordir, tetapi dibatasi hanya 3 (tiga) kali order harus lunas, apabila sampai tiga kali tidak dapat melunasi hutangnya, maka untuk order berikutnya harus dibayar kontan. Sisa hutang belum terbayar, $\mathrm{H}$. Mustakhim akan meminta jaminan yang besarnya senilai hutang pelanggan atau sekurang-kurangnya mendekati hutang pelanggan. $^{101}$

Menghadapi pelanggan yang kurang baik $\mathrm{H}$. Mustakhim memberikan jalan keluar dalam menyelesaikan hutangnya, yaitu dengan cara membayar dengan barang yang harganya disepakati antara H. Mustakhim dan pelanggannya. Barang-barang yang dapat digunakan untuk menbayar hutang tersebut seperti sepeda motor, mobil televisi dan laptop. Langkah tersebut diambil sebagai upaya untuk menagih sisa hutang pelanggan. Apabila hutang-hutang tersebut tidak ditagih, maka dapat mengganggu operasional usaha bordir milik $H$. Mustakhim,

${ }^{101}$ H. Mustakhim, Wawancara pribadi, Pemilik CV Barokhah, tanggal 5 Juli 2018. karena menyangkut biaya produksi, perawatan dan gaji karyawan. ${ }^{102}$

Dalam meminta barang-barang sebagaimana tersebut diatas, pemilik usaha bordir akan meminta secara baikbaik dan dituangkan dalam perjanjian secara tertulis dan disaksikan oleh 2 (dua) orang saksi dari kedua belah pihak. Tujuannya adalah untuk menghindari terjadinya sengketa pada kemudian hari. ${ }^{103}$

\section{Kendala-Kendala Yang Muncul Dalam Pelaksanaan Perjanjian Secara Lisan Antara Pelaku Usaha Bordir Dengan Pelanggan}

Kendala yang dihadapai oleh pengusaha ketiga usaha bordir yaitu UD Bimatex Embroidery milik Sutikman, UD Dua Putri milik H. Abdillah Noor dan CV Barokhah milik H. Mustakhim, yaitu :

a. Pelanggan mengingkari jika dirinya mempunyai hutang kepada pengusaha bordir.

Dalam KUHPerdata tidak ada pasal yang menyatakan bahwa perjanjian harus dibuat secara tertulis. Dalam KUHPerdata mengatur syarat sanya perjanjian sebagaimana diatur dalam Pasal 1320 KUHPerdata juga tidak mengatur perjanjian harus dibuat secara tertulis. Dengan demikian suatu Perjanjian yang dibuat secara lisan juga mengikat secara hukum bagi para pihak yang membuatnya, atau menganut asas pacta sun servanda, yang diatur Pasal 1338 KUHPerdata, yang menyatakan bahwa semua perjanjian yang dibuat secara sah berlaku sebagai undangundang bagi mereka yang membuatnya.

\footnotetext{
${ }^{102}$ H. Mustakhim, Wawancara pribadi, Pemilik CV Barokhah, tanggal 5 Juli 2018.

${ }^{103}$ H. Mustakhim, Wawancara pribadi, Pemilik CV Barokhah, tanggal 5 Juli 2018.
} 
Perjanjian yang dibuat secara lisan, mempunyai risiko, yaitu salah satu pihak ingkar janji (tidak mengakui hutangnya). Dalam perjanjian kerja ini, pelanggan bordir dapat saja tidak mengakui kalau dirinya mempunyai hutang. Apabila sampai terjadi pelanggan tidak mengakui hutangnya, maka pemilik usaha bordir dapat menempuh jalur hukum, apabila jalan ini ditempuh, maka pengusaha bordir harus mempunyai alat bukti, karena perjanjian dilakukan secara lisan, oleh sebab itu alat bukti yang dapat diajukan adalah saksi. Meskipun perjanjian antara pemilik usaha bordir dengan pelanggannya dilakukan secara lisan, para pihak harus mentaati perjanjian tersebut. Hal ini sebagaimana diatur Pasal 1338 KUHPerdata.

Dalam menghadapi pelanggan yang demikian, pemilik usaha bordir UD. Bimatex Embroidery Sutikman, memberikan keterangan bahwa pelanggan yang demikian memang tidak ada niat untuk membayar sisa hutangnya. Menghadapi pelanggan yang demikian, Sutikman bersikap tegas dengan menempuh jalur hukum dengan alat bukti saksi. ${ }^{104}$

Pemilik UD. Dua Putri, $\mathrm{H}$. Abdillah Noor, memberikan penjelasan bahwa salah satu pelanggannya pernah tidak mengakui jika dirinya masih mempunyai tunggakan pembayaran bordir karena terlalu lama. Abdillah Noor tidak melakukan penagihan kepada salah satu pelanggan tersebut, sehingga pelanggan mengingkari kalau

104 Sutikman, Wawancara pribadi, Pengusaha bordir, pemilik UD Bimatex Embroidery pada tanggal 9 Juli 2018. dirinya masih mempunyai tunggakan pembayaran bordir di UD Dua Putri. ${ }^{105}$

b. Pelanggan pindah rumah

Sutikman memberikan penjelasan bahwa, pelanggannya yang sudah terlalu banyak hutang, maka semua asetnya dijual dan selanjutnya pelanggan tersebut pindah rumah. Ada 2 tujuan pelanggan yang menjual asetasetnya seperti rumah dan tanah, yaitu $: 106$

a) Penjualan tersebut memang untuk melunasi hutang-hutangnya, artinya pelanggan seperti ini memang pelanggan yang baik, terhadap pelanggan yang demikian Sutikman masih memberikan toleransi.

b) Penjualan rumah pelanggan karena ingin pindah rumah dengan tujuan untuk menghindari tagihan dari pengusaha bordir. Pelanggan yang seperti ini termasuk pelanggan yang tidak baik. Niatnya memang tidak untuk melunasi hutang-hutangnya. Sutikman tidak memberikan toleransi terhadap pelanggan yang demikian. Terhadap pelanggan yang demikian pengusaha bordir menempuh jalur hukum dengan menggunakan alat bukti saksi.

c. Pelanggan susah dihubungi

Pengusaha bordir susah untuk menghubungi pelanggan karena pelanggan selain sudah pindah rumah juga tidak dapat ditelepon karena pelanggan berganti nomor ponsel. Tujuan pelanggan menganti nomor ponsel adalah untuk memutus komunikasi dengan

105 H. Abdillah Noor, Wawancara pribadi, Pengusaha Bordir UD Dua Putri, tanggal 24 Juni 2018

106 Sutikman, Wawancara pribadi, Pengusaha bordir, pemilik UD. Bimatex Embroidery pada tanggal 9 Juli 2018. 
pengusaha bordir dengan harapan tidak dikejar-kejar hutangnya.

d. Kurang bukti jika akan melakukan gugatan

Apabila terjadi sengketa di Pengadilan antara pengusaha bordir dengan pelangganya dikemudian hari, maka tidak ada alat bukti tertulis, karena perjanjian antara pengusaha bordir dengan pelanggan dilakukan secara lisan. Perjanjian yang dilakukan secara lisan antara pengusaha bordir dengan pelanggan susah untuk dibuktikan.

Namun demikian, dalam proses pembuktian suatu perkara perdata, lazimnya alat bukti yang dipergunakan oleh pihak yang mendalilkan sesuatu adalah alat bukti surat yang diatur Pasal 163 HIR yang menyatakan bahwa "Barang siapa, yang mengatakan ia mempunyai hak, atau ia menyebutkan suatu perbuatan untuk menguatkan haknya itu, atau untuk membantah hak orang lain, maka orang itu harus membuktikan adanya hak itu atau adanya kejadian itu". Hal ini karena dalam suatu hubungan keperdataan, suatu surat/akta memang sengaja dibuat dengan maksud untuk memudahkan proses pembuktian, apabila di kemudian hari terdapat sengketa perdata antara pihak-pihak yang terkait.

\section{Kesimpulan}

1. Pelaksanaan perjanjian yang dilakukan secara lisan oleh para pelaku usaha bordir yaitu UD. Bimatex Embroidery milik Sutikman, UD. Dua Putri milik H. Abdillah Noor dan CV. Barokhah milik H. Mustakhim, ketiganya masing-masing pernah mengalami membuat perjanjian secara lisan yang diingkari oleh pelanggannya atau mempunyai pelanggan yang wanprestasi. Dalam melakukan pekerjaan, antara pengusaha bordir dengan pelanggan menggunakan perjanjian lisan karena dianggap singkat dan tidak rumit. Perjanjian yang disepakatai yaitu pelanggan memberikan uang muka tanda jadi dan kekurangan pembayaran akan dilunasi jika pekerjaan bordir sudah selesai. Namun yang terjadi, tidak semua pelanggan membayar tepat pada waktunya saat pekerjaan bordir selesai.

2. Tindakan yang dilakukan pengusaha bordir terhadap pelanggan yang wanprestasi antara lain : UD. Bimatex Embroidery milik Sutikman memberikan kesempatan kepada pelanggannya untuk mengangsur sisa pembayaran yang tertunggak, UD. Dua Putri milik H. Abdillah Noor dalam menghadapi pelanggan yang wanprestasi, pemilik UD Dua Putri, tetap memberikan pelayanan jasa bordir, hal ini dikarenakan, apabila tidak diterima order bordir dari pelanggan tersebut, maka pelanggan tidak dapat mengangsur tunggakan biaya bordir yang belum terbayar dan CV. Barokhah milik H. Mustakhim dalam menghadapai pelanggan yang wanprestasi tetap memberikan pelayanan kepada pelanggan tersebut, karena memang usaha pelanggan baru mengalami kemunduran, tetapi hanya dibatasi sampai 3 (tiga) kali order bordir harus lunas.

3. Kendala-kendala yang dihadapi dalam pelaksanaan perjanjian secara lisan antara pengusaha bordir dengan pelanggan yaitu : 
a. Pelanggan mengingkari jika dirinya mempunyai hutang kepada pengusaha bordir.

b. Ada beberapa pelanggan yang pindah rumah, sehingga jarak dan waktu akan mempengaruhi pembayaran.

c. Pelanggan susah dihubungi dengan alasan yang tidak jelas.

d. Kurangnya bukti jika akan melakukan gugatan karena perjanjian dilakukan secara lisan.

\section{DAFTAR PUSTAKA}

Ahmadi Miru \& Sakka Pati, 2011, Hukum Perikatan (Penjelasan Makna Pasal 1233 sampai 1456 KUH PERDATA), Rajawali Pers, Jakarta.

Bambang Sunggono, 2012, Metodologi Penelitian Hukum, Raja Grafindo Persada, Jakarta.

Dyah Ochtorina Susanti dan A'an Efendi, 2014, Penelitian Hukum (Legal Research), Sinar Grafika, Jakarta.

Zainuddin Ali, Metode Penelitian Hukum, Sinar Grafika, 2010, Jakarta.

Subekti, 2010, Hukum Perjanjian, Intermasa, Jakarta.

\section{Peraturan Perundang-Undangan}

Undang-Undang Dasar Negara

Republik Indonesia Tahun 1945

Kitab Undang-Undang Hukum Perdata 